\title{
TRACE METAL ENVIRONMENTAL CONTAMINATION RECORDS IN CORE SEDIMENTS OF GORGAN BAY IN THE SOUTHEAST OF THE CASPIAN SEA
}

\author{
Bagheri, H. - Mahmudy Gharaie, M. H. * Moussavi Harami, R. - Khanehbad, M. \\ Department of Geology, Faculty of Sciences, Ferdowsi University of Mashhad, Mashhad, Iran \\ *Corresponding author \\ e-mail:mhmgharaie@um.ac.ir
}

(Received $4^{\text {th }}$ Nov 2018; accepted $22^{\text {nd }}$ May 2019)

\begin{abstract}
In this study five sedimentary cores were collected from Gorgan Bay (southeastern part of the Caspian Sea). Concentrations of elements were measured to determine depositional trends and geostatistical assessment of toxic elements was carried out. $\mathrm{Al}, \mathrm{Fe}, \mathrm{K}, \mathrm{Mg}, \mathrm{Na}$ and $\mathrm{S}$ content increased in all 5 cores, from the bottom to near the top layer, with maximum concentrations at $15-45 \mathrm{~cm}$ depths. However, for the toxic elements, maximum concentration of $\mathrm{As}, \mathrm{Cr}, \mathrm{Cu}, \mathrm{Pb}, \mathrm{Zn}, \mathrm{Co}$ and $\mathrm{Ni}$ varied in different depth of 5-15 cm and 80-120 cm. Enrichment factors (EFs) and pollution load index (PLI) were calculated to assess the enrichment and pollution of heavy elements in the bay sediments. Except for $\mathrm{Ca}$ and $\mathrm{S}$, all studied elements showed positive and significant correlations with $\mathrm{Fe}$ and $\mathrm{Al}$, which indicate the same source (human or natural). Principal component analysis (PCA) indicated that sediments were influenced by both geologic and anthropogenic impacts. According to the EFs, most toxic elements showed no significant enrichment and no pollution in the core sediments. Based on PLI average value in all cores, the southeast coast of the Caspian Sea (Gorgan Bay) should be classified as not metal polluted, but in recent decades there has been a dramatic increase of toxic elements that needs more attention and also monitoring.
\end{abstract}

Keywords: heavy metals, sedimentary cores, geochemistry, source

\section{Introduction}

The study of core sediments is very useful to detect different natural process such as paleoclimate changes, or anthropogenic activities on sedimentary environments (Harikumar and Nasir, 2010) by examining the geochemical and geo-statistical data (Karbassi et al., 2005; Mohamed et al., 2005; Sun et al., 2012; Vallius, 2014; Veerasingam et al., 2015). The coastal zones with their variable physical and chemical properties are suitable environment for the assessment of pollutant accumulations in aquatic ecosystems, where the bottom sediments are affected by both dissolved heavy elements or on surface absorbed particles transported from land to the basin (Harbison, 1986; Szefer et al., 1995). Heavy metal concentrations from natural and anthropogenic sources in coastal area can be increased through high input after intense rock-minerals weathering in the land or due to urbanization (Harikumar and Nasir, 2010). Anthropogenic pollutions in aquatic environments have direct influence on coastal ecosystems (Alessandro et al., 2006). In fact, core sediments obtained from the coastal areas provide a good chronological record of contamination (Morelli et al., 2012). Understanding trace metal emissions in coastal environments is an important task for researcher sand policy planners, and regulatory actions can be implemented to reduce health risks potential. 


\section{Study area}

Gorgan Bay (Southeastern part of the Caspian Sea) is a unique brackish water body, semi-confined triangular-shaped having about $500 \mathrm{~km}^{2}$ area, maximum depth of $4 \mathrm{~m}$ and average depth $1.5 \mathrm{~m}$, high ecological value and hydromorphological properties such as depth variation, freshwater flow and wave exposure. It is located at the south-east of the Caspian Sea in both Golestan and Mazandaran provinces (Fig. 1). Gorgan Bay was formed during the late Holocene period by a coastal barrier system (sandy spit) which is named Miankaleh spite (Kakroudi et al., 2012). There are no tides in the Gorgan Bay like in other parts of the Caspian Sea. It is connected to the Caspian Sea through Ashoradeh-Bandar Torkaman mouth, (Approximately; width of $400 \mathrm{~m}, 3 \mathrm{~km}$ long) with strong currents in the area affected by storm surge. Water balance in the Gorgan Bay is influenced by water evaporation, precipitation, intrusion from the Caspian Sea, and to a lesser extent by fresh river water (Sharbaty, 2011, 2012). It receives freshwater from a number of rivers and small streams, Gorgan-rud River from the north of the inlet and Qarehsu river enters from the east.

Several works on distributions of heavy metals and other pollutants have been carried out in this area (Kasymov., 1989; Tait et al., 2004; Parr et al., 2007; Karbassi et al., 2008; Bastami et al., 2012; Nasrolahi et al., 2017), but no studies have focused on the trends of metals on different core sediments in this area. The aims of the current study are: (1) to describe the vertical variation of elements from east to west of Gorgan Bay; (2) to estimate the geochemical sources of major and trace metals in sediments using coefficient correlation and principal component analysis (PCA); and (3) to assess enrichment and possible contamination of trace metals in sediments, using enrichment factors (EFs) and pollution load index (PLI).

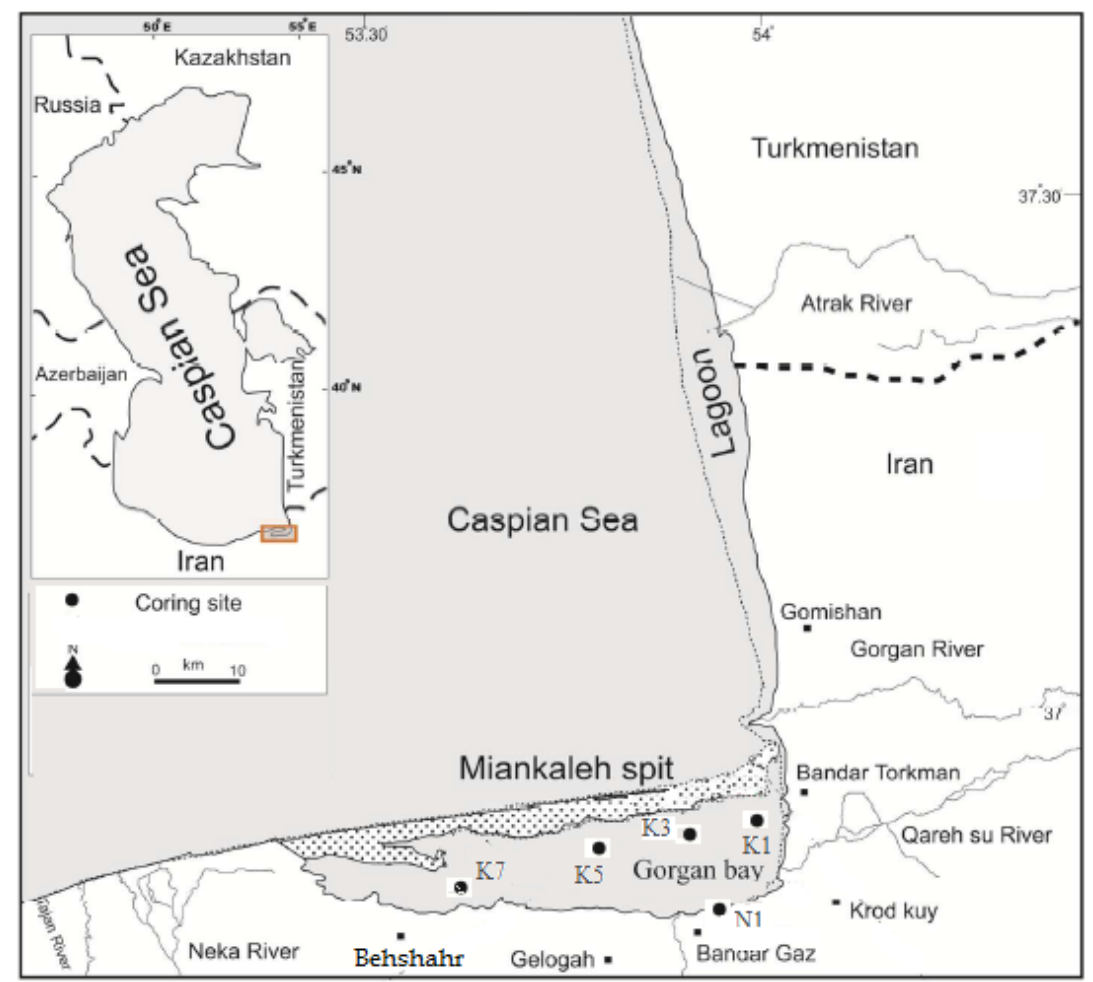

Figure 1. The locations of the core sampling sites 


\section{Materials and methods}

Five sedimentary cores with different length were collected using a gravity corer on August 2016 (Table 1). Samples were packed and carried in ice-boxes to the laboratory and stored at $4{ }^{\circ} \mathrm{C}$ until analysis. After opening the cores, about 25 subsamples picked from each core (each $5 \mathrm{~cm} 1$ subsample and totally 120 subsamples). Subsamples were dried in an oven and then powdered by using a mortar then screened with a $0.5 \mathrm{~mm}$ sieve to remove large particles. Sediment samples $(1 \mathrm{~g})$ were digested using a mixed solution of 1:3 nitric acid : hydrochloric acid for $3 \mathrm{~h}$. The solution was cooled, filtered through Whatman-42 and diluted to $50 \mathrm{ml}$ volume using distilled water (APHA et al., 2005). Concentrations of major elements (Al, Ca, Fe, K, $\mathrm{Mg}, \mathrm{Na}$, and $\mathrm{S}$ ) and trace metals (As, $\mathrm{Co}, \mathrm{Cr}, \mathrm{Cu}, \mathrm{Ni}, \mathrm{Pb}$, and $\mathrm{Zn}$ ) were measured by using inductively coupled plasma-optical emission spectrometry (ICP-OES; Varian 735 ES series), Arsenic (As) analysis was carried out by using atomic absorption spectrometry (model SOLAAR, M5) Data recoveries of the analysed element areas are the followings: $\mathrm{Al}(100 \%-101 \%), \mathrm{Ca}(97.6 \%-97.8 \%), \mathrm{Fe}(100 \%-101 \%), \mathrm{K}$ (103\%-104\%), Mg (95.1\%-95.3\%), Na (102\%-103\%), S (98.7\%-100\%), As (112\%$113 \%)$, Co $(105 \%-111 \%), \mathrm{Cr}(88.5 \%-88.7 \%), \mathrm{Cu}(98.3 \%-98.8 \%)$, Ni $(97.5 \%-$ 98.7\%), $\mathrm{Pb}(118 \%-121 \%)$, and $\mathrm{Zn}(93.2 \%-93.5 \%)$.

Table 1. Geographic position, length and depth of each core in Gorgan Bay

\begin{tabular}{c|c|c|c|c}
\hline Core name & Water depth $(\mathbf{m})$ & Core length $(\mathbf{m})$ & Longitude & Latitude \\
\hline K1 & 2.6 & 1.78 & $54^{\circ} 0^{\prime} 42.34$ & $36^{\circ} 51^{\prime} 49.9$ \\
K3 & 3.24 & 1.67 & $53^{\circ} 54^{\prime} 38.86$ & $36^{\circ} 50^{\prime} 33.5$ \\
K5 & 2.8 & 1.34 & $53^{\circ} 48^{\prime} 43.5$ & $36^{\circ} 50^{\prime} 21.35$ \\
K7 & 0.4 & 1.3 & $53^{\circ} 36^{\prime} 18.87$ & $36^{\circ} 48^{\prime} 26.31$ \\
N1 & 0.1 & 0.98 & $53^{\circ} 54^{\prime} 62.5$ & $36^{\circ} 47^{\prime} 6.19$ \\
\hline
\end{tabular}

Grain size analysis was performed using laser particle size analyzer (HORIBALA950, France \& Japan) in Iranian National Institute for Oceanography laboratory. Before analysis, about $4 \mathrm{~g}$ samples were cremated in an oven at $550{ }^{\circ} \mathrm{C}$ for $4 \mathrm{~h}$ and then at $950{ }^{\circ} \mathrm{C}$ for $1 \mathrm{~h}$ to remove organic matter and biogenic carbonate, respectively.

Pearson correlation analysis and PCA were conducted to specify geochemical associations and certainly the factors controlling the geochemical origin in coastal sediments (Bastami etal, 2014). A two-tailed Pearson correlation coefficient was used in correlation analysis. PCA was performed on a correlation matrix; N80\% of the total variance was computed for principal components. Pearson correlation coefficients and PCA were accomplished using the SPSS 20.0 software. Enrichment factor (EF) as an appropriate index was calculated to determine anthropogenic or geogenic source of the toxic elements by normalizing their concentrations according to the sediment texture properties (Morillo et al., 2004; Selvaraj et al., 2004; Adamo et al., 2005; Vald'es et al., 2005; Shi et al., 2010; Morelli et al.2012; Zhang et al., 2013). To calculate the $\mathrm{EF}, \mathrm{Al}$ is widely used in the equation as aluminum silicate, it is predominant at the coastal areas. Enrichment Factor is determined as follows (Huang and Lin, 2003; Woitke et al., 2003): 


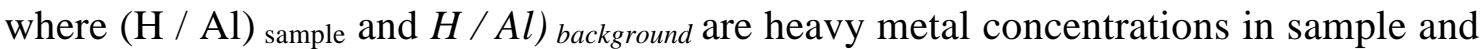
background reference, respectively. In this study, we used background concentrations of heavy metals in K5 sediment core at the depth of $85 \mathrm{~cm}$ which are 2.96, 11.50, 53.01, 14.33, 27.43, $11.80 \mathrm{ppm}$ and 41.60 for $\mathrm{As}, \mathrm{Co}, \mathrm{Cr}, \mathrm{Cu}, \mathrm{Ni}, \mathrm{Pb}$, and $\mathrm{Zn}$, respectively (De Mora et al., 2004).

\section{Results and discussion}

Vertical distributions of selected elements in cores K1, K3, K5, K7 and N1 are presented in Figure 2. A lot of runoff and eroded sediments from several sources such as human activities and river systems (Bagheri et al., 2012) enters terrigenous materials into the Gorgan Bay. Generally concentration of $\mathrm{Al}, \mathrm{Fe}, \mathrm{K}, \mathrm{Mg}, \mathrm{Na}$ and $\mathrm{S}$ increased from the bottom to the top layers in the cores, and the maximum concentrations of these major elements were observed at depths of $15-45 \mathrm{~cm}$ in all cores, while the toxic elements have different trends. In core $\mathrm{K} 1$, the highest concentrations of $\mathrm{Cr}(75.95 \mathrm{ppm}), \mathrm{Ni}(83.22 \mathrm{ppm})$ and $\mathrm{Zn}(83.22 \mathrm{ppm})$ were determined at $5 \mathrm{~cm}$ depth, As $(9.39 \mathrm{ppm})$ at $10 \mathrm{~cm}, \mathrm{Cu}(36.64 \mathrm{ppm})$ at $15 \mathrm{~cm}, \mathrm{Co}$ (21.79 ppm) at $30 \mathrm{~cm}$ and $\mathrm{Pb}(22.01 \mathrm{ppm})$ at $35 \mathrm{~cm}$ depth.

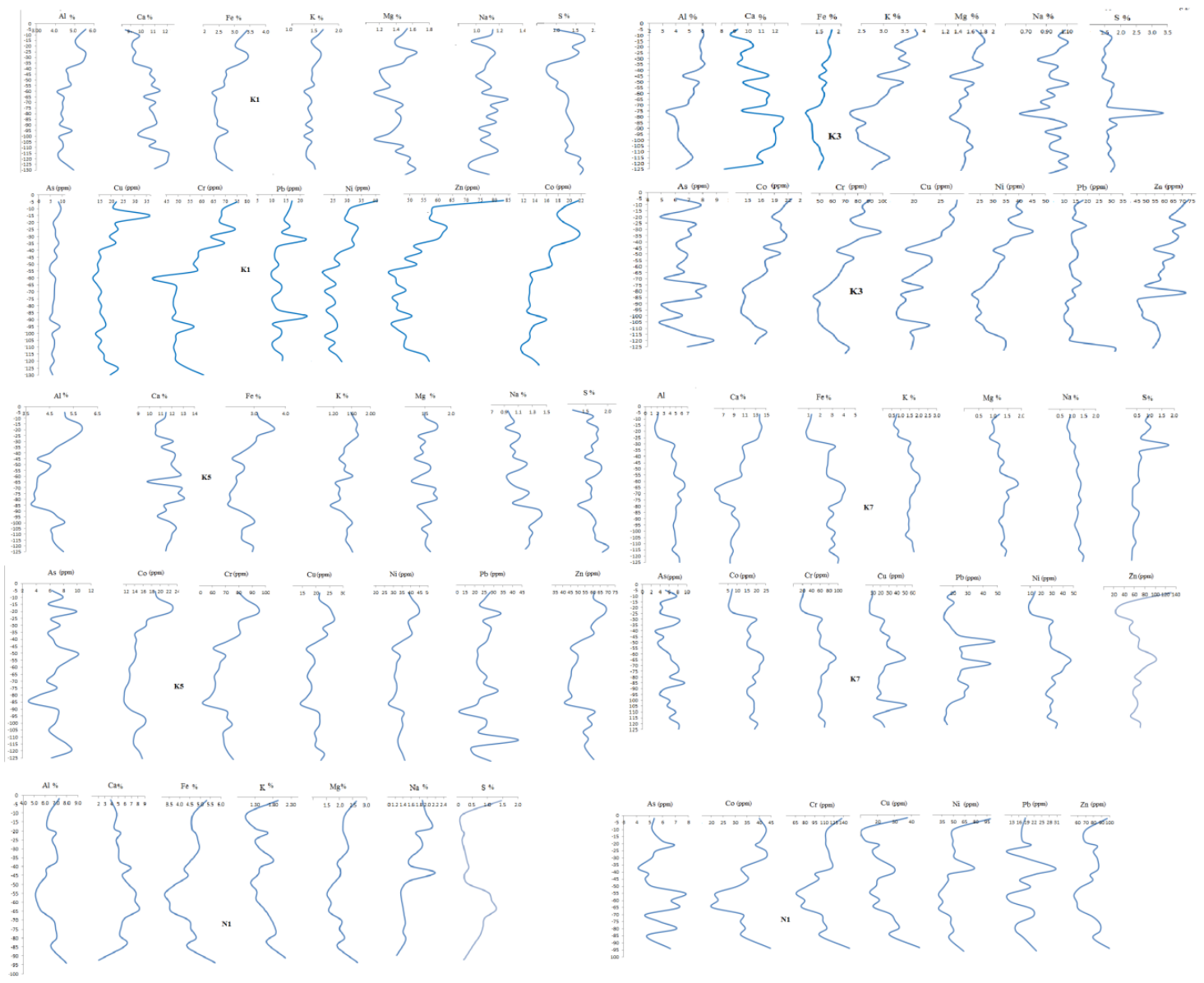

Figure 2. Vertical distributions of major and trace metals in cores 
In core $\mathrm{K} 3$, the highest concentration of $\mathrm{Cu}(28.04 \mathrm{ppm})$, Co $(22.04 \mathrm{ppm})$ and $\mathrm{Zn}$ (73.45 ppm) were observed at $5 \mathrm{~cm}$ depth, for $\mathrm{Cr}(98.44)$ and $\mathrm{Ni}(45.26 \mathrm{ppm})$ at $10 \mathrm{~cm}$ depth, and for As (8.81 ppm) and $\mathrm{Pb}(31.38 \mathrm{ppm})$ at $120 \mathrm{~cm}$ depth.

In core K5 maximum concentrations of all heavy metals were observed at a depth of 15-20 cm, expect for As (10.15) at 50 and $\mathrm{Pb}(43.08)$ at $110 \mathrm{~cm}$. opposite of this trend in west and south of Gorgan bay in the K7, N1 cores, the highest value of trace elements reported in different depths as As $(9.55,7.80 \mathrm{mg} / \mathrm{g}$ ) at 85, $55 \mathrm{~cm}$; Co (23.79, $44.79 \mathrm{mg} / \mathrm{g}) ; \mathrm{Cr}(95.11,149.4 \mathrm{mg} / \mathrm{g})$ at $65,94 \mathrm{~cm} ; \mathrm{Ni}(47.37,105.4 \mathrm{mg} / \mathrm{g})$ at 65,$5 ; \mathrm{Cu}$ $(52.05,45.20 \mathrm{mg} / \mathrm{g})$ at $105,94 \mathrm{~cm} ; \mathrm{Pb}(48.13,30.6 \mathrm{mg} / \mathrm{g})$ at $50,37 \mathrm{~cm}$ and $\mathrm{Zn}(131.6$, $106.7 \mathrm{mg} / \mathrm{g}$ ) at 5, $94 \mathrm{~cm}$ depth (Fig. 2).

Heavy metals show some information about source and migration of sediments. For example, high correlations between heavy metals probably mean these elements reflect similar origin or share analogous transformation and immigration processes in the certain situation. The major factors affecting spatial variation of trace elements in the sediments are organic matter and the grain size (Aloupi and Angelidis, 2001; Huang and Lin, 2003; Liaghati et al., 2004). The fine grains, have high surface/volume ratio and cation absorption potential, and are more effective adsorbents of contaminated organic and inorganic materials (McCave, 1984; Horowitz and Elrick, 1987). Fine-grained sediments, which contain lots of organic matter are more contaminated than coarsegrained sediments (DeMora et al., 2004). However, some studies have reported an inverse relationship between particle size and metal content (Bastami et al., 2014). In our study, in most cores, all elements showed positive and significant correlation (except for $\mathrm{Ca}$ and $\mathrm{S}$ ) with $\mathrm{Fe}$ and $\mathrm{Al}$ indicating the same origin or input source of these elements (human or natural) into the Gorgan Bay. Also, there was a positive and significant correlation between $\mathrm{As}, \mathrm{Fe}, \mathrm{Zn}, \mathrm{Cr}, \mathrm{Ni}, \mathrm{Cu}$ and $\mathrm{K}$, indicating that these elements have the same origin and the same behavior in the studied area. Sulfur and calcium had a negative correlation with most of the heavy metals which indicates different origin or behavior of these elements in the environment. Also, in core N1, arsenic had a negative correlation with most metals while it was positively correlated with calcium and showed negative correlation with iron and aluminum, which probably indicates the biological origin of this metalloid.

Three principal components (PC) were extracted from the core K1 sediments, which accounted for about $81.74 \%$ of the total variance. The first component (PC1) accounted for $58.21 \%$, the second component (PC2) accounted for $14.26 \%$ and the third component (PC3) accounted for $8.22 \%$ of the total variance (Fig. 3). In PC1 high loadings of major elements ( $\mathrm{Al}, \mathrm{Fe}, \mathrm{K}$ and $\mathrm{Ca}$ ) and heavy metals $(\mathrm{Co}, \mathrm{Cr}, \mathrm{Ni}, \mathrm{As}, \mathrm{Cu}, \mathrm{Pb}$ and $\mathrm{Zn}$ ) were observed (from 0.617 to 0.958 ). The elements $\mathrm{Al}$, Fe and $\mathrm{K}$ mainly represent lithogenic origin after weathering and erosion of rocks and soil parent materials, PC1 described the lithogenic source bound in aluminosilicate minerals. The second component (PC2) also showed $\mathrm{Mg}$ and $\mathrm{S}$ with moderate to high loadings (0.791$0.901)$ and $\mathrm{Na}$ with high loading counted in the third component (PC3).

In core $\mathrm{K} 3$, we extracted $3 \mathrm{PCs}$, which accounted for about $82.43 \%$ of the total variance (Fig. 4). Based on the loading distribution of the variable elements, $\mathrm{Al}, \mathrm{Ca}, \mathrm{Fe}$, $\mathrm{K}, \mathrm{Mg}, \mathrm{Cr}, \mathrm{Ni}, \mathrm{Cu}, \mathrm{Co}$ and $\mathrm{Zn}$ constituted a firmly related group (PC1) with $55.81 \%$ of the total variance. While another group was composed of Na and S (PC2) with 14.24\% of the total variance. The third component (PC3) accounted for $12.37 \%$ and had high loadings on $\mathrm{As}$ and $\mathrm{Pb}$. These results may indicate the different origins or controlling factors of the heavy metal distributions in the Gorgan Bay sediments. In this area, the 
lithogenic source acted as the main factor accounting for PC1, while PC2 and PC3 may be derived from the urban source.

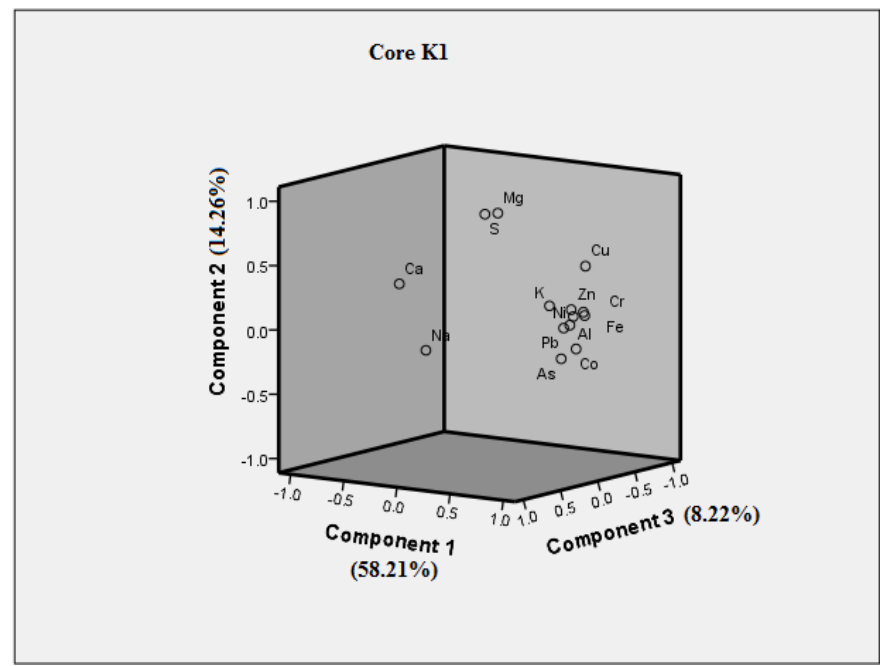

Figure 3. PCA plot of elements in core $K 1$

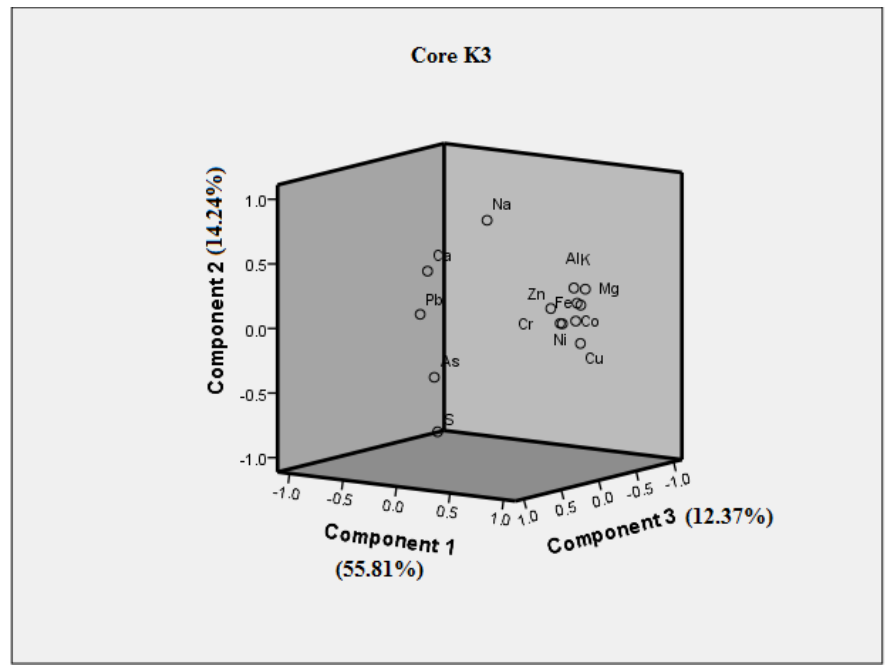

Figure 4. PCA plot of elements in core $\mathrm{K} 3$

In core $\mathrm{K} 5$, we extracted $3 \mathrm{PCs}$, which accounted for about $80.26 \%$ of the total variance (Fig. 5). The first component (PC1) accounted for $55.30 \%$ of the total variance and included all variable element except for $\mathrm{Na}, \mathrm{S}, \mathrm{Pb}$ and $\mathrm{As}$, while the second component (PC2) accounted for $14.37 \%$ with high loading on $\mathrm{Na}, \mathrm{S}$ and As (0.61-.82) and the PC3 accounted for $10.58 \%$ with high loading on $\mathrm{Pb}$.

In core K7 (Fig. 6) that was obtained from west of the Gorgan Bay, 3 PCs were extracted and total variance was $86.55 \%$ (Fig. 5). In this core unlike in the other 4 cores $\mathrm{Na}$ and $\mathrm{S}$ with other elements ( $\mathrm{Al}, \mathrm{Ca} \mathrm{Fe}, \mathrm{K}, \mathrm{Mg}, \mathrm{Cr}, \mathrm{Ni}, \mathrm{Cu}$, and $\mathrm{Co}$ ), $\mathrm{Zn}$ with high loading on $\mathrm{PC} 2$, and $\mathrm{Pb}$ and As show loading on PC3, which accounted $65.11 \%$, $11.79 \%$ and $9.65 \%$ respectively. In the studied area PCA showed anthropogenic input of $\mathrm{Pb}$ and $\mathrm{Zn}$ from the industrial activities (anthropogenic source), which are widely used 
as the main components in several industrial processes. In fact, those elements were partially derived from the anthropogenic source.

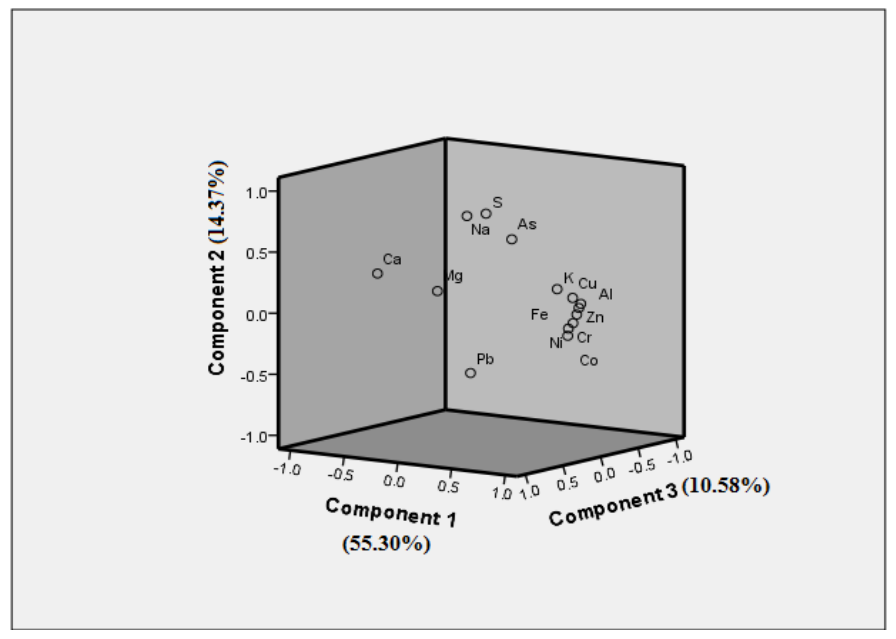

Figure 5. PCA plot of elements in core K5

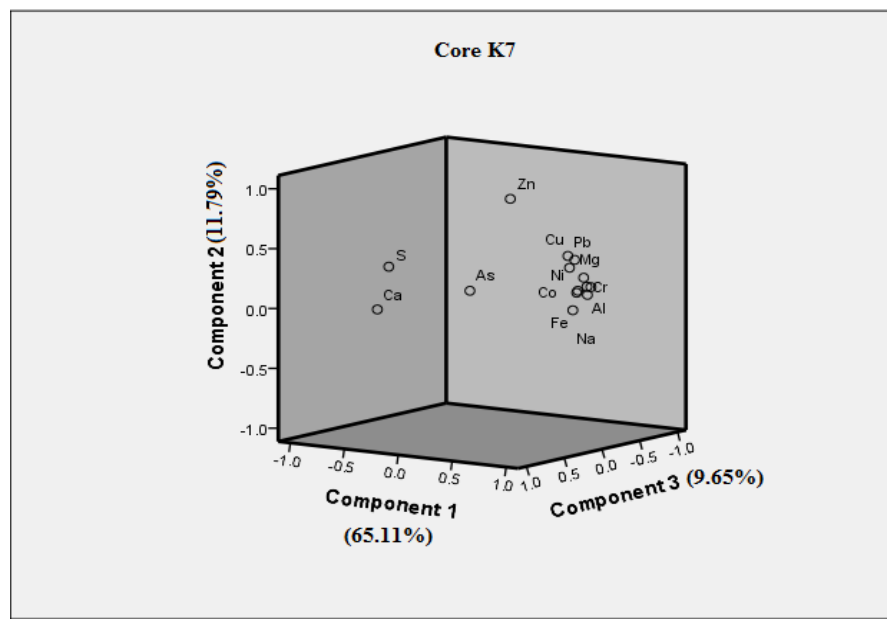

Figure 6. PCA plot of elements in core $K 7$

Finally in core N1 (Fig. 7), 3 extracted PCs accounted for about $86.89 \%$ of the total variance. The PC1, PC2 and PC3 were $54.31 \%, 20.15 \%$ and $12.42 \%$ of the total variance, respectively (Fig. 5). The first principal component (PC1) included all elements expect for $\mathrm{Na}$ and $\mathrm{S}$ (that are considered as $\mathrm{PC} 2$ ) and $\mathrm{As}, \mathrm{Pb}$ (that are considered as PC3) were lithogenic source. The PC2 also showed that $\mathrm{Cu}, \mathrm{Co}, \mathrm{Pb}$ and $\mathrm{Zn}$ had loadings on (0.16-0.63), indicating that these elements were partially derived from the anthropogenic source. Overall, all metals in the Gorgan bay sediments were mostly derived from the geologic origin (geogenic), except for western part of the bay, where the toxic elements were mainly derived from terrestrial discharge of industrial activities (anthropogenic).

Enrichment factor is a useful index to assess the heavy metals contamination in the soil and sediments (Feng et al., 2004; Reddy et al., 2004; Han et al., 2006; Chen, 2007; Çevik et al., 2009; Bastami et al., 2012). EF values are interpreted as; $\mathrm{EF}<1$, no 
enrichment; EF 1 to 3, minor enrichment; EF 3 to 5, moderate enrichment; EF 5 to 10, moderately severe enrichment; EF 10 to 25, severe enrichment; EF 25 to 50, very severe enrichment and EF > 50 extremely severe enrichment (Grant and Middleton, 1990; Loska et al., 1997; Abrahim and Parker, 2008). In this study, EF values in all core samples ranged in no-enrichment $(\mathrm{EF}<1)$ to minor enrichment (EF 1 to 3 ) suggesting no anthropogenic enrichment of the toxic elements, except for $\mathrm{Pb}$ and $\mathrm{Zn}$ in core7, which show moderate enrichment of these elements (EF 3-5) and indicate that anthropogenic source of $\mathrm{Zn}$ and $\mathrm{Pb}$ were significantly polluted the sediments of core 7 (Fig. 8).

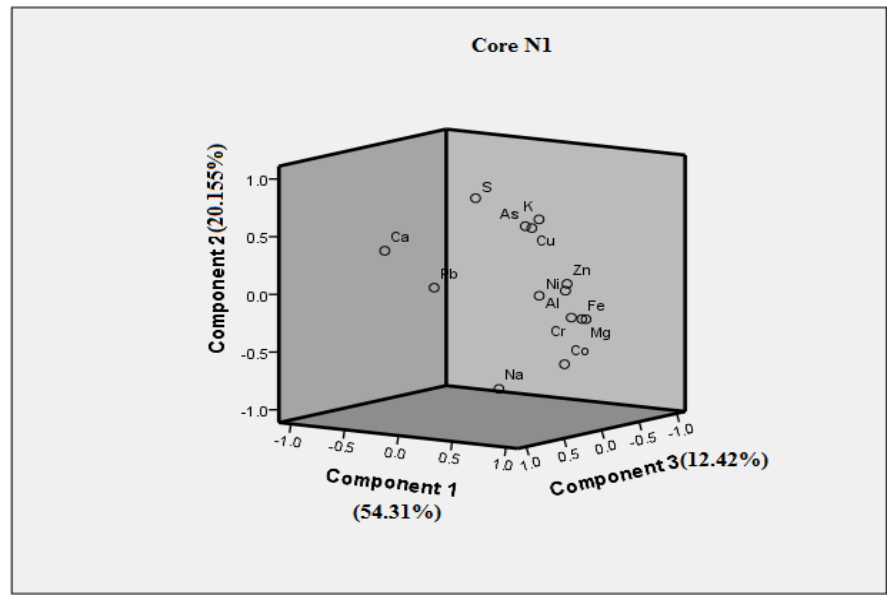

Figure 7. PCA plot of elements in core N1

To assess the sediment environmental quality, an integrated pollution load index (PLI) of seven toxic elements was calculated as suggested by Suresh et al. (2011).

$$
\mathrm{PLI}=(\mathrm{CF} 1 \times \mathrm{CF} 2 \times \mathrm{CF} 3 \times \ldots \ldots \mathrm{CFn}) 1 / \mathrm{n}
$$

An area with PLI value $>1$ is polluted whereas PLI value $<1$ indicates no contamination (Chakravarty and Patgiri, 2009; Seshan et al., 2010). Concentrations of the elements in shale (sedimentary rock), which refer to the average concentration of the earth crust (Turekian and Wedepohl, 1961), were used as the reference baselines in this study. The PLI was calculated for all five studied cores and based on seven toxic elements of $\mathrm{As}, \mathrm{Pb}, \mathrm{Co}, \mathrm{Cr}, \mathrm{Ni}, \mathrm{Cu}$, and $\mathrm{Zn}$ (Table 2). The maximum and the minimum calculated PLI were 1.07 and 0.26 , respectively (Table 2).

Table 2. Comparison of toxic metals in each cores (ppm) with base value and PLI

\begin{tabular}{|c|c|c|c|c|c|c|c|c|c|c|c|c|c|c|c|}
\hline \multirow{2}{*}{ Metals } & \multicolumn{3}{|c|}{ K1 } & \multicolumn{3}{|c|}{ K3 } & \multicolumn{3}{|c|}{ K5 } & \multicolumn{3}{|c|}{ K7 } & \multicolumn{3}{|c|}{ N1 } \\
\hline & $\operatorname{Ave} \pm$ Std & Max & Min & Ave \pm Std & Max & Min & Ave \pm Std & Max & Min & Ave \pm Std & Max & Min & Ave \pm Std & Max & Min \\
\hline As & $6.65 \pm 1.28$ & 9.39 & 4.70 & $6.60 \pm 1.03$ & 8.81 & 4.84 & $6.93 \pm 1.60$ & 10.15 & 2.96 & $6.11 \pm 1.79$ & 9.55 & 2.89 & $5.76 \pm 1.06$ & 7.80 & 4.12 \\
\hline Co & $15.63 \pm 3.16$ & 21.79 & 11.68 & $16.78 \pm 3.53$ & 22.81 & 11.68 & $15.19 \pm 3.01$ & 22.81 & 11.50 & $16.20 \pm 5.34$ & 23.79 & 5.37 & $34.63 \pm 7.40$ & 44.79 & 20.24 \\
\hline $\mathrm{Cr}$ & $56.38 \pm 9.68$ & 75.08 & 38.89 & $67.41 \pm 14.4$ & 98.44 & 44.88 & $71.76 \pm 10.3$ & 94.24 & 53.01 & $57.43 \pm 20.92$ & 95.11 & 15.32 & $106.35 \pm 21.14$ & 149.60 & 65.89 \\
\hline $\mathrm{Cu}$ & $17.96 \pm 4.99$ & 36.64 & 12.14 & $21.72 \pm 3.65$ & 28.04 & 16.80 & $20.44 \pm 3.05$ & 26.63 & 14.33 & $22.80 \pm 12.23$ & 52.04 & 6.01 & $24.09 \pm 8.98$ & 45.20 & 11.31 \\
\hline $\mathbf{N i}$ & $27.26 \pm 4.44$ & 40.49 & 21.26 & $32.07 \pm 6.28$ & 45.26 & 21.99 & $35.15 \pm 4.4$ & 44.58 & 27.43 & $28.15 \pm 9.92$ & 47.37 & 8.78 & $50.32 \pm 17.78$ & 105.40 & 30.01 \\
\hline $\mathbf{P b}$ & $13.41 \pm 3.31$ & 22.46 & 9.88 & $15.43 \pm 5.24$ & 31.38 & 10.16 & $25.15 \pm 5.8$ & 43.08 & 11.80 & $22.93 \pm 8.60$ & 48.13 & 14.33 & $18.34 \pm 4.73$ & 30.60 & 10.95 \\
\hline Zn & $52.33 \pm 8.72$ & 83.22 & 42.66 & $59.36 \pm 8.24$ & 73.45 & 46.09 & $54.50 \pm 7.8$ & 68.37 & 41.60 & $66.32 \pm 22.01$ & 131.60 & 23.86 & $78.14 \pm 13.45$ & 106.70 & 55.45 \\
\hline PLI & \multicolumn{3}{|c|}{0.57} & \multicolumn{3}{|c|}{ 0.63 } & \multicolumn{3}{|c|}{0.63} & \multicolumn{3}{|c|}{0.71} & \multicolumn{3}{|c|}{0.83} \\
\hline
\end{tabular}




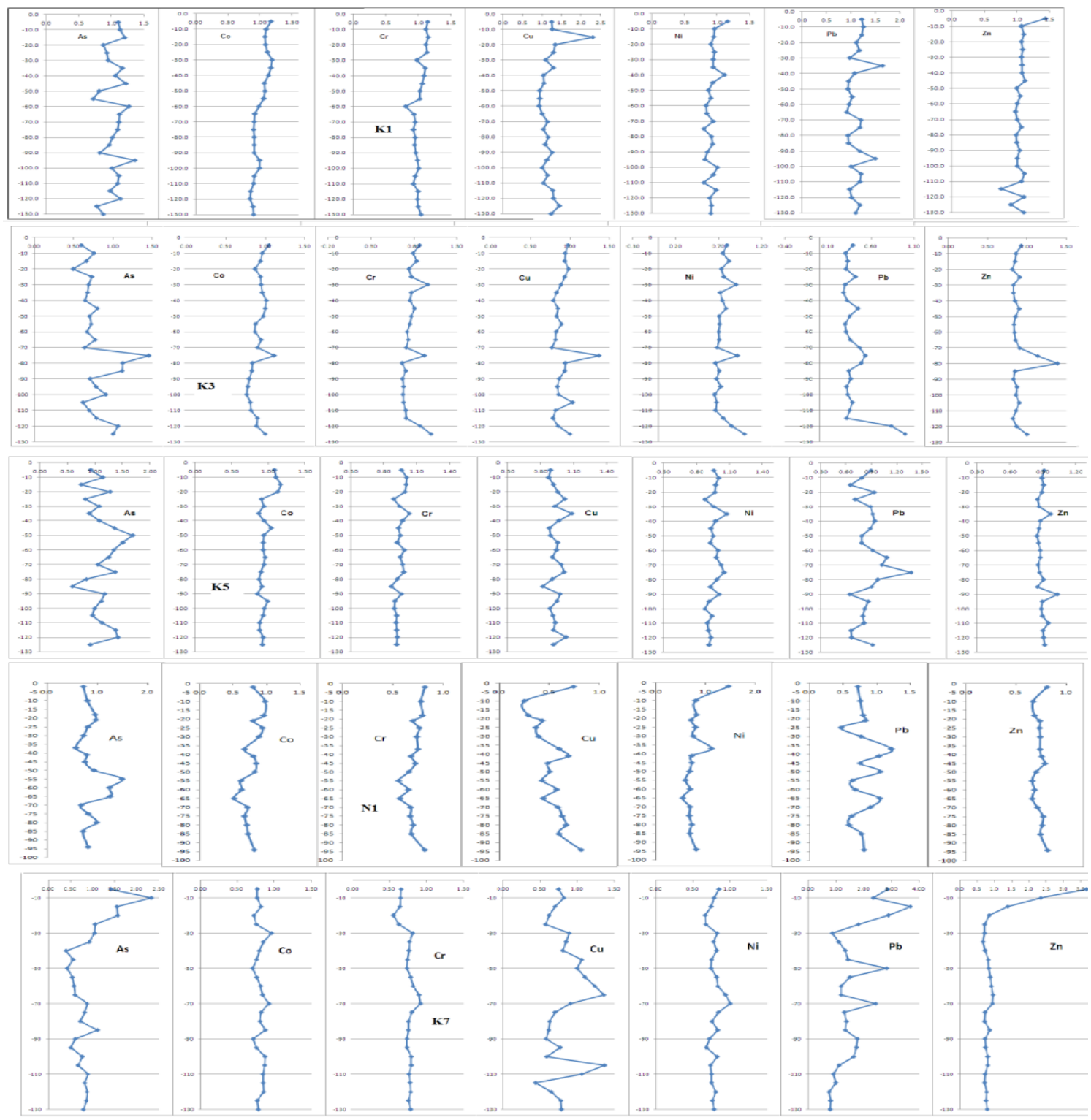

Figure 8. Enrichment factor trend of heavy metals in cores

Results showed that the PLI value of the elements in average sediment was lower than that in surface sediment in cores $\mathrm{K} 1, \mathrm{~K} 3, \mathrm{~K} 5, \mathrm{~K} 7$ and $\mathrm{N} 1$, which can be attributed to direct discharges from urban area and fisheries boats carrying toxic elements, contaminants in study areas, especially in core N1 area. Based on average of PLI value in all cores, southeast coast of the Caspian Sea (Gorgan Bay) should be classified as no toxic pollution (Table 3), but in recent decades there has been a dramatic increase that needs more attention and consideration. Finally, comparison of toxic elements with the quality guidelines (NOAA, ISQG) showed the range between the two guideline (level of some elements as $\mathrm{As}, \mathrm{Ni}, \mathrm{Cu}, \mathrm{Pb}$ was higher than ERL and lower than ERM). However, because of ecosystem condition, tourism and aquatic resources, this area, must be prevented, managed and monitored properly before they constitute a serious threat to the health of the environment and the organisms. 
Table 3. Comparison of this study with other studies and quality guidelines

\begin{tabular}{c|c|c|c|c|c|c|c|c}
\hline Region & $\mathbf{P b}(\mathbf{p p m})$ & $\mathbf{C u}(\mathbf{p p m})$ & $\mathbf{Z n}(\mathbf{p p m})$ & $\mathbf{A s}(\mathbf{p p m})$ & $\mathbf{N i}(\mathbf{p p m})$ & $\mathbf{C o}(\mathbf{p p m})$ & $\mathbf{C r}(\mathbf{p p m})$ & Reference \\
\hline Gorgan Bay & $9.88-43.8$ & $6.01-45.2$ & $23.8-106.18$ & $2.89-10.15$ & $8.78-105.4$ & $5.37-44.8$ & $15.3-149.6$ & This study \\
\hline $\begin{array}{c}\text { Southeast coast } \\
\text { of the Caspian } \\
\text { Sea }\end{array}$ & $\begin{array}{c}13.00 \pm 3.14 \\
(9-16)\end{array}$ & $\begin{array}{c}9.09 \pm 3.16 \\
(5-14)\end{array}$ & $\begin{array}{c}28.00 \pm 5.71 \\
(22.33-36.33)\end{array}$ & $\begin{array}{c}4.11 \pm 1.27 \\
(2.36-5.16)\end{array}$ & $\begin{array}{c}17.42 \pm 3.78 \\
(16.33-24)\end{array}$ & - & - & $\begin{array}{c}\text { Bastami et } \\
\text { al. (2014) }\end{array}$ \\
\hline $\begin{array}{c}\text { Caspian Sea } \\
\text { (Iran) }\end{array}$ & $\begin{array}{c}18.0 \pm 4.17 \\
(11.3-24.6)\end{array}$ & $\begin{array}{c}34.7 \pm 11.9 \\
(13.2-50.9)\end{array}$ & $\begin{array}{c}85.3 \pm 17.9 \\
(55.9-146)\end{array}$ & $\begin{array}{c}12.5 \pm 3.04 \\
(6.97-20.1)\end{array}$ & $\begin{array}{c}51.6 \pm 11.8 \\
(29.4-67-8)\end{array}$ & $\begin{array}{c}15.9 \pm 4 \\
(6.9-24.2)\end{array}$ & $\begin{array}{c}85.2 \pm 15.3 \\
(59.6-128)\end{array}$ & $\begin{array}{c}\text { De Mora et } \\
\text { al. (2004) }\end{array}$ \\
\hline $\begin{array}{c}\text { Jurujuba sound } \\
\text { (Brazil) }\end{array}$ & $\begin{array}{c}61 \pm 35 \\
(5-123)\end{array}$ & $\begin{array}{c}51 \pm 40 \\
(5-213)\end{array}$ & $\begin{array}{c}158 \pm 97 \\
(15-337)\end{array}$ & - & $\begin{array}{c}48 \pm 19 \\
(15-79)\end{array}$ & - & $\begin{array}{c}89 \pm 19 \\
(15-79)\end{array}$ & $\begin{array}{c}\text { Baptista } \\
\text { Neto et al. } \\
(2001)\end{array}$ \\
\hline $\begin{array}{c}\text { Black Sea } \\
(2.1-43.5)\end{array}$ & $\begin{array}{c}30.67 \pm 18.76 \\
(4.61-75.72)\end{array}$ & $\begin{array}{c}69.00 \pm 57.03 \\
(1-174)\end{array}$ & - & $49.8 \pm 34.81$ \\
$(1-117)$ & $\begin{array}{c}20.76 \pm 18.55 \\
(1.57-71.59)\end{array}$ & $\begin{array}{c}57.2 \pm 41.85 \\
(1-120)\end{array}$ & $\begin{array}{c}\text { Secrierus } \\
\text { and } \\
\text { Secrierus } \\
(2002)\end{array}$ \\
\hline Mediterranean \\
Sea
\end{tabular}

$\mathrm{ERL}=$ Effect range low $(\mathrm{NOAA}) ; \mathrm{ERM}=$ Effect range medium $(\mathrm{NOAA}) ; \mathrm{ISQG}=$ Interim sediment quality guideline (Environment Canada); PEL = Probable effects level (Environment Canada)

\section{Conclusion}

In this study concentrations and geochemical trends of some major elements (Al, Fe, $\mathrm{K}, \mathrm{Mg}, \mathrm{Na}$ and $\mathrm{S}$ ) and heavy metals (As, $\mathrm{Cu}, \mathrm{Ni}, \mathrm{Co}, \mathrm{Pb}, \mathrm{Cr}, \mathrm{Zn}$ ), in 5 cores from Gorgan Bay were determined. in all $\mathrm{K} 1, \mathrm{~K} 3, \mathrm{~K} 5, \mathrm{~K} 7, \mathrm{~N} 1$ cores major element concentrations increased from the bottom to the top layer, and the maximum concentrations of these major elements in cores were observed at depths of 15-45 cm. All elements showed a positive and significant correlation (except $\mathrm{Ca}$ and $\mathrm{S}$ ) with $\mathrm{Fe}$ and $\mathrm{Al}$ and represent the same input source (human or natural), also there was a positive and significant correlation between arsenic, $\mathrm{Fe}, \mathrm{Zn}, \mathrm{Cr}, \mathrm{Co}, \mathrm{Ni}, \mathrm{Cu}$ and $\mathrm{K}$, indicating that these metals have the same origin and the same behaviour in this area. Sulfur and calcium had a negative correlation with most of the heavy metals which indicates different behaviour and origin of these elements in the environment. PCA represent all metals were mostly derived from the geological origin in sediments of the Gorgan Bay, except for western part which was mainly derived from terrestrial discharge of industrial activities. EF values in all cores ranged no enrichment $(\mathrm{EF}<1)$ to minor enrichment (EF 1 to 3) suggesting no anthropogenic enrichment, expect $\mathrm{Pb}$ and $\mathrm{Zn}$ in core 7 showed moderate enrichment (EF 3-5) which indicated that anthropogenic Zn and $\mathrm{Pb}$ enriched and polluted significantly sediment core 7 . Based on the average of PLI values for these 5 cores and 7 trace metals ( $\mathrm{As}, \mathrm{Co}, \mathrm{Cr}, \mathrm{Cu}, \mathrm{Ni}, \mathrm{Pb}$, and $\mathrm{Zn}$ ), the southeast coast of the Caspian Sea (Gorgan Bay) should be classified as no metal pollution but in recent decades there has been a dramatic increase specially in the coastal area of $\mathrm{K} 7$, that needs more attention and consideration.

Acknowledgements. This study has been supported by Ferdowsi University of Mashhad-international Campus. The study was conducted as PhD thesis (\#3/41676) contribution of the first author (H. B.). We 
are grateful to Mr. Nyestani, Shimiyar Analytical Laboratories Ltd. in Tehran, for providing information on the methods and standard specifications which helped in the completion of this paper.

\section{REFERENCES}

[1] Abrahim, G. M. S., Parker, R. J. (2008): Assessment of heavy metal enrichment factors and the degree of contamination in marine sediments from Tamaki Estuary, Auckland, New Zealand. - Estuarine, Coastal and Shelf Science 136: 227-238.

[2] Adamo, P., Arienzo, M., Imperato, M., Naimo, D., Nardi, G., Stanzione, D. (2005): Distribution and partition of heavy metals in surface and sub-surface sediments of Naples city port. - Chemosphere 61: 800-809.

[3] Alessandro, B., Giovanni, B., Nicola, C. (2006): Heavy metals in marine sediments of Taranto Gulf (Ionian Sea, southern Italy). - Mar. Chem. 99: 227-235.

[4] Aloupi, M., Angelidis, M. O. (2001): Geochemistry of natural and anthropogenic metals in the coastal sediments of the island of Lesvos, Aegean Sea. - Journal of Environmental Pollution 113: 211-219.

[5] APHA, AWWA, WEF (2005): Standard Methods for Examination of Water and Wastewater. - APHA, AWWA, WEF, Washington, DC.

[6] Baptista Neto, J. A., Smith, B. J., McAllister, J. J. (2001): Heavy metal concentrations in surface sediments in a near shore environment, Jurujuba Sound, Southeast Brazil. Environmental Pollution 109: 1-9.

[7] Bagheri, H., Lahijani, H., Kakroodi, A. (2012): Mineralogy of Late Quaternary Sediments in Miankalehspite. - Iranian National Institute for Oceanography and Atmospheric Science, Tehran (Persian report).

[8] Bastami, K., Bagheri, H., Haghparast, S., Soltani, F., Hamzehpoor, A., Bastami, M. D. (2012): Geochemical and geo-statistical assessment of selected heavy metals in the surface sediments of the Gorgan Bay, Iran. - Marine Pollution Bulletin 64: 2877-2884.

[9] Bastami, K., Bagheri, H., Kheirabadi, V., GhorbanzadehZaferani, G., Teymori, M. B., Hamzehpoor, A., Soltani, F., Haghparast, S., MoussaviHarami, S. R., FarzanehGhorghani, N., Ganji, S. (2014): Distribution and ecological risk assessment of heavy metals in surface sediments along southeast coast of the Caspian Sea. - Marine Pollution Bulletin 81(1): 262-267.

[10] Çevik, F., Göksu, M. Z. L., Derici, O. B., Fındık, Ö. (2009): An assessment of metal pollution in surface sediments of Seyhan dam by using enrichment factor, geoaccumulation index and statistical analyses. - Environmental Monitoring and Assessment 152: 309-317.

[11] Chakravarty, M., Patgiri, A. D. (2009): Metal pollution assessment in sediments of the Dikrong River, NE India. - Journal Human Ecology 27(1): 63-67.

[12] Chen, W. Q. (2007): Heavy metal contamination in western Xiamen Bay sediments and its vicinity, China. - Marine Pollution Bulletin 54: 974-982.

[13] De Mora, S., Sheikholeslami, M., Wyse, E., Azemard, S., Cassi, R. (2004): An assessment of metal contamination in coastal sediments of the Caspian Sea. - Marine Pollution Bulletin 48(1-2): 61-77.

[14] Feng, H., Han, X., Zhang, W., Yu, L. (2004): A preliminary study of heavy metal contamination in Yangtze River intertidal zone due to urbanization. - Marine Pollution Bulletin 49(11-12): 910-915.

[15] Grant, A., Middleton, R. (1990): An assessment of metal contamination of sediments in the Humber Estuary. - Estuarine, Coastal and Shelf Science 31: 71-85.

[16] Han, Y., Du, P., Cao, J., Eric, S. P. (2006): Multivariate analysis of heavy metal contamination in urban dusts of Xi'an Cent, China. - The Science of the Total Environment 355: 176-186. 
[17] Harbison, P. (1986): Mangrove muds: a sink and a source for trace metals. - Mar. Pollut. Bull. 17(6): 246-250.

[18] Harikumar, P. S., Nasir, U. P. (2010): Ecotoxicological impact assessment of heavy metals in core sediments of a tropical estuary. - Ecotoxicol. Environ. Saf. 73: 1742-1747.

[19] Horowitz, A. J., Elrick, K. A. (1987): The relation of stream sediment surface area, grain size and composition to trace element chemistry. - Applied Geochemistry 2: 437-451.

[20] Huang, K. M., Lin, S. (2003): Consequences and implication of heavy metal spatial variations in sediments of the Keelung River drainage basin, Taiwan. - Chemosphere 53: $1113-1121$

[21] Huang, J. X., Yin, Y., Xu, J., Zhu, X. B. (2007): Spatial accumulation features and environment efficiency of heavy metals in intra-tidal surface sediments of Guanhe estuary, Northern Jiangsu. - Mar. Geol. Quat. Geol. 27(5): 23-32.

[22] Kakroodi, A, A., Kroonenberg, S., Hoogendoorn, R. (2012): Rapid Holocene sea-level changes along the Iranian Caspian coast. - Quaternary International 263: 93-103.

[23] Karbassi, A. R., Nabi-Bidhendi, G. R., Bayati, I. (2005): Environmental geochemistry of heavy metals in a sediment core of Bushehr, Persian Gulf, Iran. - J. Environ. Health Sci. Eng. 2(4): 255-260.

[24] Karbassi, A. R., Nouri, J., Mehrdadi, N., Ayaz, G. O. (2008): Flocculation of heavy metals during mixing of freshwater with Caspian Sea water. - Environ. Geol. 53: 18111816.

[25] Kasymov, A. G. (1989): Abundance of zooplankton and zoobenthos in Baku Bay, Caspian Sea. - Oceanology 28(4): 524.

[26] Liaghati, T., Preda, M., Cox, M. (2004): Heavy metal distribution and controlling factors within coastal plain sediments, Bells Creek catchment, southeast Queensland, Australia. Environment International 29: 935-948.

[27] Long, E. R., Mac Donald, D. D., Smith, S. L., Calder, F. D. (1995): Incidence of adverse biological effects within ranges of chemical concentrations in marine and estuarine sediments. - Environmental Management 19: 18-97.

[28] Loska, K., Cebula, J., Pelczar, J., Wiechuła, D., Kwapulinski, J. (1997): Use of enrichment and contamination factors together with geo accumulation indexes to evaluate the content of $\mathrm{Cd}, \mathrm{Cu}$, and $\mathrm{Ni}$ in the Rybnik water Reservoir in Poland. - Water, Air, and Soil Pollution 93: 347-365.

[29] McCave, I. N. (1984): Size spectra and aggregation of suspended particles in the deep ocean. - Deep Sea Research 31(4): 329-352.

[30] Mohamed, A. W. (2005): Geochemistry and sedimentology of core sediments and the influence of human activities, Qusier, Safaga and Hasighada Harbors, Red sea coast Egypt. - Egypt. J. Aquat. Res. 31(1): 92-103.

[31] Moreno, M., Albertelli, G., Fabiano, M. (2009): Nematode response to metal, PAHs and organic enrichment in tourist marinas of the Mediterranean Sea. - Marine Pollution Bulletin 58: 1192-1201.

[32] Morelli, G., Gasparon, M., Fierro, D., Hu, W. P., Zawadzki, A. (2012): Historical trends in tracemetal and sediment accumulation in intertidal sediments of Moreton Bay, southeast Queensland, Australia. - Chem. Geol. 300-301: 152-164.

[33] Morillo, J., Usero, J., Gracia, I. (2004): Heavy metal distribution in marine sediments from the southwest coast of Spain. - Chemosphere 55: 431-442.

[34] Nasrolahi, A., Smith, B. D., Ehsanpour, M.; Afkhami, M., Rainbow, P. S. (2017): Biomonitoring of trace metal bioavailability in the barnacle along the Iranian coast of the Caspian Sea. - Iranian Journal of Fisheries Sciences 16(1)1-25.

[35] Parr, T. D., Tait, R. D., Maxon, C. L., Newton, F. C., Hardin, J. L. (2007): A descriptive account of benthic macrofauna and sediment from an area of planned petroleum exploration in the southern Caspian Sea. - Estuarine, Coastal and Shelf Science 71: 170180. 
[36] Reddy, M. S., Basha, S., Kumar, V. G. S., Joshi, H. V., Ramachandraiah, G. (2004): Distribution, enrichment and accumulation of heavy metals in coastal sediments of Alange Sosiya ship scrapping yard, India. - Marine Pollution Bulletin 48: 1055-1059.

[37] Secrierus, D., Secrierus, A. (2002): Heavy metal enrichment of man-made origin of superficial sediment on the continental shelf of the north-western Black Sea. - Estuarine Coastal Shelf Science 54: 513-526.

[38] Selvaraj, K., Ram Mohan, V., Szefer, P. (2004): Evaluation of metal contamination in coastal sediments of the Bay of Bengal, India: Geochemical and statistical approaches. Marine Pollution Bulletin 49: 174-185.

[39] Seshan, B. R. R., Natesan, U., Deepthi, K. (2010): Geochemical and statistical approach for evaluation of heavy metal pollution in core sediments in southeast coast of India. International Journal Environment Science Technology 7(2): 291-306.

[40] Sharbaty, S. (2011): Two dimensional simulation of flow pattern in Gorgan Bay by using Mike21 software. - Journal of Water and Soil Conservation 18(4): 241-246.

[41] Sharbaty, S. (2012): 3-D simulation flow pattern in the Gorgan Bay in during summer. International Journal of Engineering Research and Applications (IJERA) 2(3)700-707.

[42] Shi, G., Chen, Z., Xu, S., Zhang, J., Wang, L., Bi, C. Teng, J. (2008): Potentially toxic metal contamination of urban soils and roadside dust in Shanghai, China. - Environ. Pollut. 156: 251-260.

[43] Sun, Q. L., Liu, D. Y., Liu, T., Di, B. P., Wu, F. (2012): Temporal and spatial distribution of trace metals in sediments from the northern Yellow Sea coast, China: implications for regional anthropogenic processes. - Environ. Earth Sci. 66: 697-705.

[44] Suresh, G., Ramasamy, V., Meenakshisundaram, V., Venkatachalapathy, R., Ponnusamy, V. (2011): Influence of mineralogical and heavy metal composition on natural radionuclide contents in the river sediments. - Applied Radiation and Isotopes 69: 14661474.

[45] Szefer, P., Glassby, P., Pempkowiak, J., Kaliszan, R. (1995): Extraction studies of heavy metalpollution in surfacial sediments from the southern Baltic Sea off Poland. - Chem. Geol.120: 111-126.

[46] Tait, R. D., Maxonm, C. L., Parr, T. D., Newton, F. C., Hardin, J. L. (2004): Impact assessment and benthic recruitment following exploration drilling in the south Caspian Sea. - 7th SPE international Conference on Health, Safety, and Environment in oil and Gas Exploration, Calgary, Canada, Mar 29-31.

[47] Turekian, K. K., Wedepohl, K. H. (1961): Distribution of the elements in some major units of the earth crust. - Geol. Soc. Am. Bull. 72: 175-192.

[48] Vallius, H. (2014): Heavy metal concentrations in sediment cores from the northern BalticSea: declines over the last two decades. - Mar. Pollut. Bull. 79: 359-364.

[49] Vald'es, J., Vargas, G., Sifeddine, A., Ortlieb, L., Guinez, M. (2005): Distribution and enrichment evaluation of heavy metals in Mejillones Bay Northern Chile: geochemical and statistical approach. - Marine Pollution Bulletin 50: 1558-1568.

[50] Veerasingam, S., Vethamony, P., Mani, M. R., Fernandes, B. (2015): Depositional record of trace metals and degree of contamination in core sediments from the Mandovi estuarine mangrove ecosystem, west coast of India. - Mar. Pollut. Bull. 91: 362-367.

[51] Woitke, P., Wellmitz, J., Helm, D., Kube, P., Lepom, P., Litheraty, P. (2003): Analysis and assessment of heavy metal pollution in suspended solids and sediments of the river Danube. - Chemosphere 51: 633-642.

[52] Zhang, R., Zhang, F., Ding, Y. J., Gao, J. R., Chen, J., Zhou, L. (2013): Historical trends in the anthropogenic heavy metal levels in the tidal flat sediments of Lianyungang, China. - J. Environ. Sci. (China) 25(7): 1458-1468. 